\title{
Potensi Perikanan Air Tawar Sebagai Daya Dukung Minawisata Di Kelurahan Cibunigeulis Kota Tasikmalaya
}

\author{
Elgar Balasa Singkawijaya ${ }^{1, a}$, Siti Fadjarajani ${ }^{2, b}$ \\ 1,2 Jurusan Pendidikan Geografi, Fakultas Keguruan dan Ilmu Kependidikan, Universitas Siliwangi \\ Jalan Siliwangi No. 24 Kode Pos 46115 Kota Tasikmalaya, Indonesia
}

\begin{abstract}
Abstrak: Kota Tasikmalaya sejak tahun 2001 mengalami pertumbuhan dan perkembangan yang pesat karena didukung dengan berlakunya otonomi daerah. Wilayah Kelurahan Cibunigeulis yang berada di Kecamatan Bungursari merupakan wilayah yang unggul dengan potensi budi daya perikanan air tawar dan juga memiliki nilai potensi untuk digunakan dengan membangun kegiatan minawisata. Adapun tujuan penelitian adalah untuk mengetahui karakteristik sektor perikanan air tawar sebagai daya dukung minawisata dan bentuk kegiatan potensi minawisata. Metode yang digunakan dalam penelitian ini adalah metode deskriptif kuantitatif. Hasil penelitian menunjukkan kegiatan pemeliharaan ikan dari segi lokasi yaitu dengan kondisi fisik dan daya dukung tempat pemeliharan yang ideal seperti kolam, tenaga kerja, pembibitan, pengetahuan dan modal. Dalam proses tahapan dalam mengelola pemeliharaan ikan yang baik dan benar sehingga menghasilkan produk yang baik, diantaranya adalah tahap persiapan kolam, tahap pemupukan, tahap pemijahan, tahap penetasan telur menjadi larva ikan. Setelah itu memasuki tahap pendederan, tahap pembesaran, tahap pemanenan, tahap pengolahan dan tahap pemasaran. Adapun ikan yang di pelihara merupakan komoditas utama untuk kebutuhan konsumsi baik dalam kota dan luar kota. Beberapa produk ikan diantaranya ikan mas, ikan lele, ikan mujair, ikan nila, ikan nilem dan ikan lainnya. Untuk kegiatan dalam skala usaha skala usaha besar, sedang dan kecil. Dari segi luas kolam, sebagian besar pembudi daya memiliki skala usaha besar dengan luas kolam lebih dari $400 \mathrm{~m}^{2}$. Dari segi penggunaan tenaga kerja sebagian besar pembudi daya ikan termasuk dalam skala usaha kecil. Adapun daya dukung untuk kegiatan minawisata diantaranya kegiatan pemancingan, kuliner produk makanan lokal dan pameran ikan.
\end{abstract}

Kata Kunci: Potensi, Perikanan Air Tawar, Kawasan, Minawisata.

\section{A. PENDAHULUAN}

Kota Tasikmalaya sejak tahun 2001

mengalami pertumbuhan dan perkembangan yang pesat karena didukung dengan berlakunya otonomi daerah. Sehingga Kota Tasikmalaya mendapat kewenangan mengatur perekonomian yang sesuai karakteristik yang dimiliki. Tahun 2016 struktur perekonomian Kota Tasikmalaya dalam Badan Pusat Statistik Kota Tasikmalaya (2017) memperlihatkan karakteristik perkotaan yaitu didominasi oleh sektor tersier. Berdasarkan data Produk Domestik Regional Bruto atas dasar harga konstan tahun 2010, pada tahun 2016 sektor tersier yang terdiri dari bidang jasa mampu mencapai pendapatan sebesar Rp. 8,7 
Triliun. Sektor sekunder yang terdiri dari bidang industri mencapai Rp. 3,8 Triliun dan sektor primer yang terdiri dari pertanian dan perikanan sebesar Rp. 0,6 Triliun.

Wilayah Kecamatan Bungursari merupakan wilayah yang unggul dalam pengembangan sektor primer diantaranya pertanian dan perikanan. BPS Kota Tasikmalaya (2017) mencatat bahwa Kecamatan Bungursari pada tahun 2015 luas lahan perikanan mencapai 130,33 hektar dan juga memiliki produksi ikan tertinggi di Kota Tasikmalaya sebanyak $1.802,93$ ton.

Perikanan menurut Banowati dan Sriyanto (2013) dan Nurdin, dkk (2017) adalah usaha yang aktivitasnya meliputi penangkapan, budidaya ikan, pengolahannya hingga pemasaran hasilnya baik yang diolah maupun tidak. Adapun potensi perikanan di Kecamatan Bungursari sangat tinggi didukung oleh faktor fisik seperti ketersediaan sumber daya air, ketersediaan lahan, suhu yang tidak terlalu tinggi karena ketinggian wilayahnya 430 meter di atas permukaan laut. Faktor lokasi, sosial dan demografi juga ikut mempengaruhi, diantaranya jarak ke pusat kota yang cukup jauh karena sebagian besar wilayahnya merupakan wilayah hinterland dan berbatasan langsung dengan Kabupaten Tasikmalaya. Hal ini berdampak pada tingkat kepadatan penduduk yang tidak terlalu tinggi yaitu 2.815 orang per $\mathrm{km}^{2}$ karena masyarakat lebih memilih lokasi yang lebih dekat dengan kota.

Karakteristik sektor perikanan air tawar menurut Subarnas, dkk. (2007: 48) terdiri dari tempat pemeliharaan, jenis ikan yang dipelihara. Sedangkan usaha sektor perikanan menurut Ayodya (2010:9) diklasifikasikan berdasarkan modal dan skala. Adapun kelurahan yang sangat berpotensi dalam sektor perikanan adalah Kelurahan Cibunigeulis. Berdasarkan data BPS Kecamatan Bungursari 2018, Kelurahan Cibunigeulis memiliki luas lahan yang digunakan sebagai kolam seluas 38,33 hektar dan menempati urutan pertama diantara kelurahan lainnya di Kecamatan Bungursari.

Kondisi geologis Kelurahan Cibunigeulis dipengaruhi letusan gunungapi Galunggung yang mengalami erupsi pada tahun 1982. Abu dan lahar dingin letusan gunungapi Galunggung berdampak pada pemukiman dan jalan yang pada waktu itu masih termasuk ke dalam wilayah administratif Kecamatan Indihiang. Sehingga wilayah secara keseluruhan terdiri dari dari batuan-batuan dan material pasir hasil ledakan Gunungapi Galunggung. Hal ini menyebabkan tanah di Kelurahan Cibunigeulis menjadi subur dan baik untuk pertanian dan perikanan.

Dalam data Rencana Pembangunan 
Tahunan Kelurahan Cibunigeulis Tahun 2018 tercatat potensi sumber daya air yang cukup tinggi. Dengan menggunakan analisis Location Quotient, memiliki nilai sumber daya air 1,25 . Nilai yang lebih dari satu ini menunjukkan bahwa sumber daya air merupakan faktor unggulan yang spesialisasinya lebih tinggi daripada potensi sumber daya air di tingkat Kecamatan Bungursari. Nilai Location Quotient sumber daya air yang diperoleh menunjukkan angka yang tinggi dibandingkan kelurahan lainnya.

Kelurahan Cibunigeulis memiliki potensi yang tinggi sebagai sektor perikanan air tawar. Potensi ini dimanfaatkan oleh masyarakat dalam bentuk budi daya ikan. Sektor perikanan air tawar mempengaruhi terhadap kondisi sosial ekonomi masyarakat yang ada di Kelurahan Cibunigeulis. Selain digunakan sebagai wilayah kegiatan budi daya perikanan, juga memiliki nilai potensi untuk digunakan dengan membangun kegiatan minawisata.

Minawisata adalah kegiatan kepariwisataan dengan pendekatan pada pengembangan kegiatan pariwisata, perikanan dan kebaharian. Secara konseptual minawisata mengikuti kegiatan prinsip pengembangan ekowisata dalam bentuk menjaga kelestarian lingkungan, membangun pendidikan masyarakat, partisipasi masyarakat dan meningkatkan ekonomi masyarakat lokal. Untuk itu diperlukan daya dukung serta pengembangan dari potensi perikanan air tawar yang ada di daerah tersebut sehingga nanti menjadi sebagai kawasan minawisata di Kota Tasikmalaya. Adapun tujuan penelitian adalah untuk mengetahui karakteristik sektor perikanan air tawar sebagai daya dukung minawisata dan bentuk kegiatan dari nilai potensi minawisata di Kelurahan Cibunigeulis Kecamatan Bungursari Kota Tasikmalaya.

\section{B. METODE PENELITIAN}

Metode yang digunakan dalam penelitian ini adalah metode penelitian deskriptif kuantitatif. Metode deskriptif kuantitatif menurut Priyono (2016:37) adalah penelitian yang dilakukan untuk memberikan gambaran suatu gejala atau fenomena. Adapun variabel penelitian yang digunakan sebagai berikut:

a. Karakteristik perikanan air tawar diantaranya lokasi dan tempat pemeliharaan ikan, jenis ikan, sistem pemeliharaan dan proses produksi, modal dan skala usaha.

b. Bentuk kegiatan dari nilai potensi kawasan berdasarkan kekuatan (strengths), kelemahan (weaknesses), peluang (opportunities), dan ancaman (threats)

Sedangkan teknik pengumpulan data yang digunakan sebagai berikut:

a. Observasi pada aktivitas perikanan air tawar 
b. Wawancara ditujukan kepada

Cibunigeulis

petani ikan, Lurah Kelurahan

C. HASIL DAN PEMBAHASAN

Cibunigeulis, Penyuluh Perikanan, dan masyarakat yang memiliki keterkaitan dengan sektor perikanan.

c. Kuisioner pengumpulan data berdasarkan variabel yang akan diukur. Kuesioner diberikan kepada para pembudi daya ikan, pengolah ikan, dan buruh pembudi daya ikan.

Populasi penelitian ini adalah orang yang memiliki usaha perikanan air tawar berjumlah 129 orang, penyuluh perikanan berjumlah 1 orang, kelompok pengolahan ikan berjumlah 11 orang dan buruh perikanan berjumlah 30 orang. Sampel yang digunakan adalah stratified random sampling yang dibagi menjadi 3 lapisan yang homogen yaitu pembudi daya, pengolah ikan, dan buruh ikan sebanyak 39 orang. Dan purposive sampling menarik sampel sebanyak 2 (dua) orang yaitu penyuluh perikanan Kecamatan 1. Hasil Penelitian

Perikanan air tawar yang berada di Kelurahan Cibunigeulis Kecamatan Bungursari Kota Tasikmalaya, memiliki sumber air untuk pemanfaatan perikanan air tawar baik dari air tanah dan air permukaan. Air permukaan tersebut sebenarnya berasal dari air tanah di perbukitan sekitar namun muncul ke permukaan sebagai mata air. Wilayah perbukitan dapat menjadi catchment area ketika hujan karena juga belum terlalu padat penduduk sehingga penyerapan air dapat maksimal dan hanya sedikit yang menjadi run off. Melihat data curah hujan selama 10 tahun terakhir, termasuk dalam iklim agak basah dengan rata-rata curah hujan lebih dari $100 \mathrm{~mm}$ setiap tahunnya. Daftar sumber mata air yang ada di Kelurahan Cibunigeulis tersaji pada tabel 1 sebagai berikut:

Bungursari dan lurah Kelurahan

Tabel 1. Data Rencana Pembangunan Kelurahan Cibunigeulis

\begin{tabular}{rll}
\hline \multicolumn{1}{c}{ No } & Nama Sumber Daya Air & \multicolumn{1}{c}{ Lokasi } \\
\hline $\mathbf{1}$ & Leuwikidang & RT/RW 03/02 \\
\hline $\mathbf{2}$ & Gunung Muncang & RT/RW 01/05 \\
\hline $\mathbf{3}$ & Cihejo & RT/RW 04/05 \\
\hline $\mathbf{4}$ & Gunung Cariu Cayur & RT/RW 01/06 \\
\hline $\mathbf{5}$ & Gunung Cariu & RT/RW 02/06 \\
\hline $\mathbf{6}$ & Legok Nangka & RT/RW 03/06 \\
\hline $\mathbf{7}$ & Gunung Kokosan & RT/RW 04/06 \\
\hline $\mathbf{8}$ & Ranca Cihideung & RT/RW 03/07 \\
\hline $\mathbf{9}$ & Gunung Goong & RT/RW 02/08 \\
\hline
\end{tabular}

Sumber: Data Rencana Pembangunan Kelurahan Cibunigeulis 2018 
Sektor perikanan air tawar sebagai mata pencaharian masyarakat terdiri dari budi daya ikan air, pekerja yang membantu pembudi daya dan pengolahan ikan.

Berikut data kepemilikan lahan kolam ikan tersaji pada tabel 2 sebagai berikut:

Tabel 2. Kepemilikan dan Luas Lahan Kolam Ikan

\begin{tabular}{rlcc}
\hline No & \multicolumn{1}{c}{ Lokasi } & Kepemilikan Kolam & Luas (Ha) \\
\hline $\mathbf{1}$ & Kp. Gunung Cariu & 34 & 10 \\
\hline $\mathbf{2}$ & Kp. Rancapasung & 11 & 3 \\
\hline $\mathbf{3}$ & Kp. Pasir Angin & 14 & 3 \\
\hline $\mathbf{4}$ & Kp. Leuwibudah & 30 & 9 \\
\hline $\mathbf{5}$ & Kp. Sindang Wangi & 16 & 3 \\
\hline $\mathbf{6}$ & Kp. Gunung Kokosan & 12 & 3 \\
\hline $\mathbf{7}$ & Kp. Gunung Mareme & 14 & 3 \\
\hline $\mathbf{8}$ & Jalan Cipanas Galunggung & 12 & 2 \\
\hline $\mathbf{9}$ & Kp. Legok Nangka & 10 & 2 \\
\hline & & 153 & 38 \\
\hline
\end{tabular}

Sumber: Dinas Pertanian dan Perikanan Kota Tasikmalaya Tahun (2019)

Sebaran kolam ikan sangat ada mendapatkan dari sisa saluran air dan dipengaruhi oleh letak dan ketinggian dari saluran air persawahan. Berikut peta sumber mata air dan saluran air. Beberapa persebaran kolam ikan di Kelurahan diantaranya langsung menggunakan Cibunigeulis tersaji pada gambar 1 sebagai sumber air yang berasal dari mata air dan berikut:

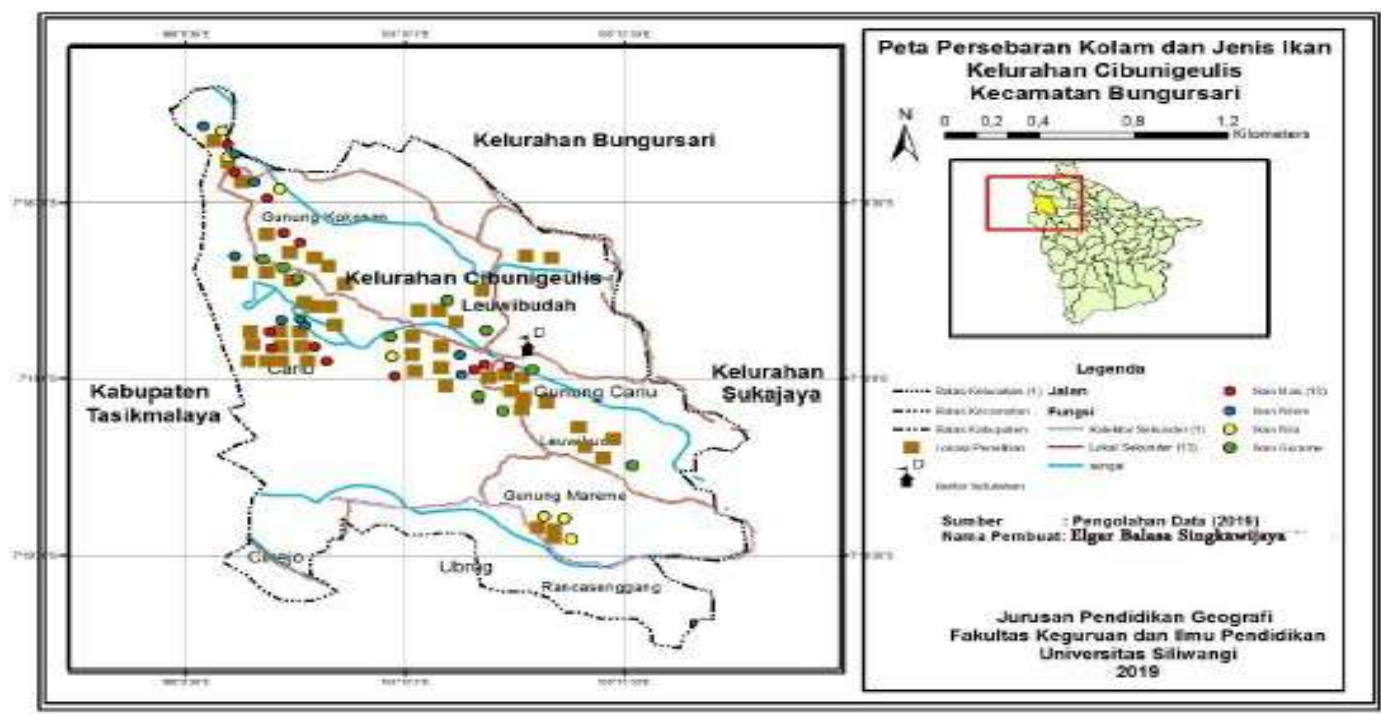

Gambar 1. Peta Sebaran Kolam dan Jenis Ikan. Sumber: pengolahan data penelitian (2019)

Tempat pemeliharan ikan bergantung dari jenis dan ukuran yang digunakan. Hal ini nantinya mempengaruhi tingkat jumlah ikan, kerapatan, sirkulasi air dan debit air yang digunakan. Jika jumlah ikan melebihi 
kapasitas maka sulit untuk berkembang, Berikut tempat pemeliharaan ikan dan namun jika sangat sedikit dapat berdasarkan jenisnya tersaji pada tabel 3 mengurangi tingkat produktifitas yang ada. sebagai berikut :

Tabel 3. Tempat Pemeliharaan Ikan

\begin{tabular}{|c|c|c|c|}
\hline No & Tempat Pemeliharaan Ikan & Jenis & Jumlah \\
\hline \multirow[t]{4}{*}{1} & \multirow[t]{4}{*}{ Kolam } & Kolam semen & 12 \\
\hline & & Kolam tanah & 13 \\
\hline & & Kolam campuran semen dan tanah & 4 \\
\hline & & Keramba & 1 \\
\hline 2 & Sawah & Minapadi & - \\
\hline 3 & Sungai & Keramba & - \\
\hline \multirow[t]{2}{*}{4} & Kolam dan sawah & Kolam dan sawah & 3 \\
\hline & & Juml & 33 \\
\hline
\end{tabular}

Sumber: Pengolahan Data Penelitian (2019)

Skala usaha yang dilakukan sangat pembesaran, dan pemijahan. Semakin luas bergantung dari luasan kegiatan usaha budi kegiatan perikanan ini maka dikatakan daya ikan itu sendiri. Skala usaha kegiatan memiliki skala usaha yang cukup besar. budidaya ini sangat bergantung dari Berikut data ukuran kepemilikan lahan kebutuhan pemanfaatan aktifitas perikanan budi daya perikanan tersaji pada tabel 4 yang ada. Dan juga sangat bergantung dari sebagai berikut:

jenis ikan unmtuk kegiatan pembenihan,

Tabel 4. Skala Usaha Berdasarkan Luas Budi Daya Perikanan Air Tawar

\begin{tabular}{rcc}
\hline No & Luas Lahan (meter) & Keterangan \\
\hline $\mathbf{1}$ & $<200$ & 3 pemilik \\
\hline $\mathbf{2}$ & $200-400$ & 5 pemilik \\
\hline $\mathbf{3}$ & $>400$ & 22 pemilik \\
\hline & Sumber: Pengolahan Data Penelitian (2019)
\end{tabular}

Kolam ikan yang digunakan kegiatan budi daya ikan air tawar yang ada memiliki ragam bentuk yang akan di Kelurahan Cibunigelis tersaji pada disesuaikan dengan kebutuhan yang ada. gambar 2 sebagai berikut:

Berikut kolam yang digunakan untuk 


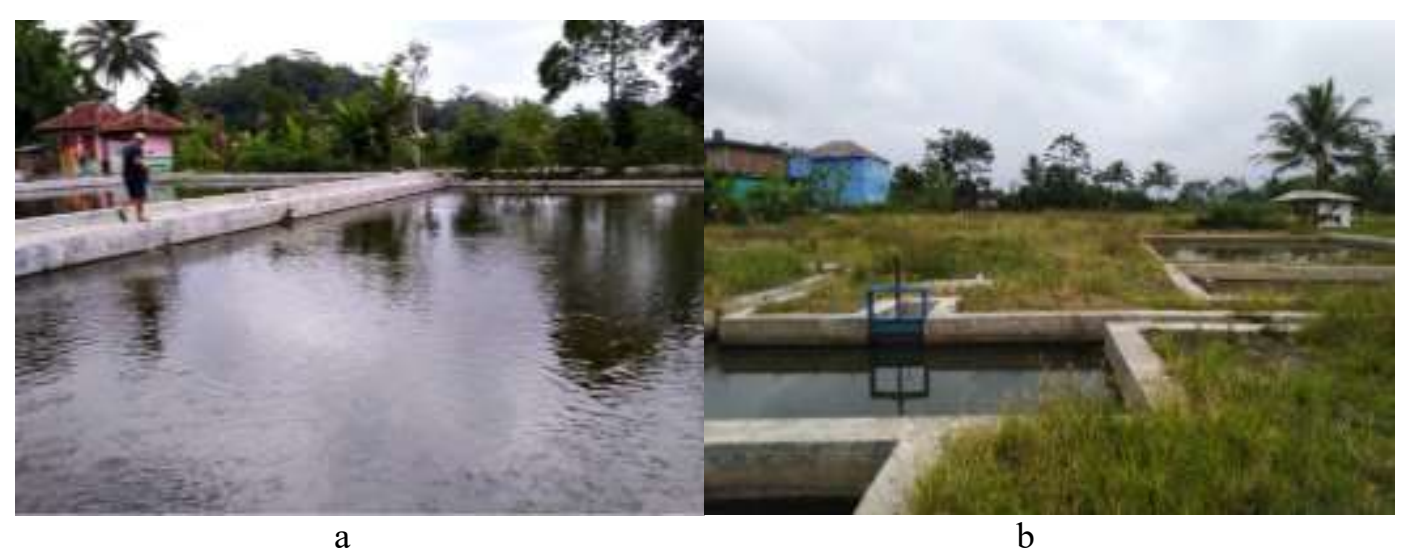

Gambar 2. Kolam Untuk Budidaya Perikanan (a) Kepemilikan Kolam Pribadi dan (b) Kepemilikan kolam secara bersama. Sumber: Dokumentasi Foto Penelitian (2019)

Sistem pemeliharaan yang dan untuk yang sudah dewasa bisa dilakukan adalah dengan memberi pangan yang diberikan cukup beragam. Mulai dari kutu air untuk ukuran ikan kecil (burayak) diberikan pelet, daun-daunan dan bekatul. Berikut data pemberian jenis pakan tersaji pada tabel 5 dan gambar 3 sebagai berikut:

Tabel 5. Jenis Pakan yang Diberikan Kepada Ikan

\begin{tabular}{lll}
\hline No & \multicolumn{1}{c}{ Jenis Pakan } & \multicolumn{1}{c}{ Keterangan } \\
\hline $\mathbf{1}$ & Kutu air & Diberikan pada ikan yang masih kecil (burayak) \\
\hline $\mathbf{2}$ & Daun dan pakan alami & $\begin{array}{l}\text { Diberikan pada ikan dewasa untuk jenis ikan mas, ikan } \\
\text { gurame dan ikan lele }\end{array}$ \\
\hline $\mathbf{3}$ & Pelet & $\begin{array}{l}\text { Di berikan pada ikan dewasa untuk jenis ikan mas, ikan } \\
\text { nila, ikan gurame, ikan tawes, ikan nilem, ikan lele, ikan } \\
\text { mujair dan ikan tambakan }\end{array}$ \\
\hline $\mathbf{4}$ & $\begin{array}{l}\text { Bekatul dan kotoran } \\
\text { ayam }\end{array}$ & $\begin{array}{l}\text { Di berikan pada ikan dewasa untuk jenis ikan mas, ikan } \\
\text { nila, ikan gurame, ikan tawes, ikan nilem, ikan lele, ikan } \\
\text { mujair dan ikan tambakan }\end{array}$ \\
\hline
\end{tabular}

Sumber: Pengolahan Data Penelitian (2019)

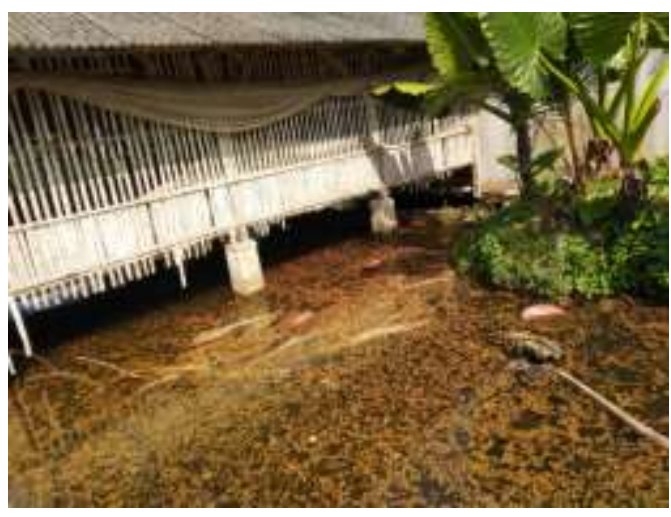

a

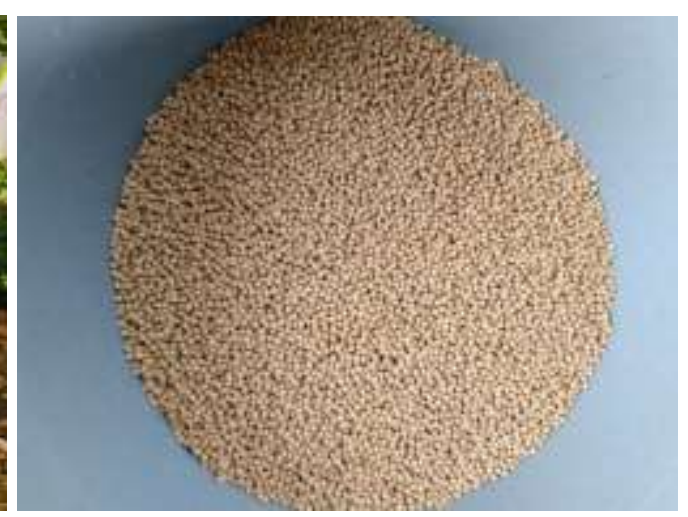

b

Gambar 3. Pakan Ikan (a) Pakan Kotoran Hewan Ayam dan Daun keladi dan (b) Pelet Ikan. Sumber: Dokumentasi Foto Penelitian (2019) 
Jenis ikan yang dibudidayakan lebih banyak pada jenis ikan konsumsi atau untuk kebutuhan pangan. Beberapa ikan yang dibudidayakan antara lain ikan mas, ikan nila, ikan gurame, ikan tawes, ikan nilem, ikan lele, ikan mujair, ikan tambakan dan ikan lainnya.

Beberapa bentuk kegiatan minawisata yang dapat dilakukan di perikanan air tawang Kelurahan
Cibunigeulis di antaranya memancing, kuliner dan pameran ikan. Sektor perikanan air tawar di Kelurahan Cibunigeulis dianalisis dengan SWOT. Strategi dapat diambil dengan memanfaatkan kekuatan dan peluang serta memperkecil kelemahan dan ancaman. Berikut adalah identifikasi SWOT untuk kegiatan minawisata tersaji pada tabel 6 sebagai berikut:

\section{Tabel 6. Analisis SWOT Perikanan Air Tawar}

\section{Kekuatan (Strengths)}

1. Kolam ikan yang bisa digunakan untuk kegiatan pemancingan.

2. Produk olahan ikan sebagai cita rasa kuliner lokal.

3. Kegiatan pameran ikan konsumsi dan ikan hias.

\section{Peluang (Opportunities)}

1. Ragam jenis kolam ikan yang bisa digunakan untuk kegiatan pemancingan.

2. Produk olahan ikan yang beragam mulai dari ikan bakar, ikan goreng, ikan pepes, ikan balado, pindang ikan, acar ikan, asam manis ikan, sate ikan, baso ikan, keripik ikan, kerupuk ikan, abon ikan dan gepuk ikan.

3. Pameran ikan menjadikan kegiatan edukasi bagi masyarakat.

\section{Kelemahan (Weakness)}

1. Kolam ikan harus dipelihara dengan baik.

2. Makanan cita rasa lokal belum dimunculkan.

3. Belum ada kegiatan pameran ikan.

\section{Ancaman (Threats)}

1. Kolam ikan bisa mengalami kekurangan debit air ketika musim kemarau jika tidak dikelola dengan baik.

2. Banyak produk olahan ikan yang kurang baik dari segi kebersihan.

3. Kurang promosi akan menyebabkan kegiatan minawisata tidak akan bisa berlanjut.

Sumber: Pengolahan Data Penelitian (2019)

\section{Pembahasan}

Kondisi geologis dari letusan gunungapi Galunggung yang mengalami erupsi pada tahun 1982 mempengaruhi kondisi fisik Kelurahan Cibunigeulis di Kota Tasikmalaya. Abu dan lahar dingin letusan gunungapi berdampak pada kawasan pemukiman termasuk kegiatan perekonomian. Sehingga wilayah secara keseluruhan terdiri dari dari batuan-batuan dan material pasir hasil ledakan Gunungapi Galunggung menyebabkan tanah di 
Kelurahan Cibunigeulis menjadi subur dan baik untuk pertanian dan perikanan. Sedangkan secara litologi terbentuk dari batuan-batuan dan abu Gunung Galunggung.

Jenis tanah mendominasi permukaan adalah tanah regosol kelabu, litosol berwarna coklat dan latosol coklat kemerah-merahan.Tanah regosol memiliki struktur lepas dengan tekstur pasir sampai berlempung dengan warna tanah coklat yang terdapat di wilayah bergelombang hingga dataran tinggi. Tanah latosol berwarna merah, coklat sampai kekuningkuningan dengan zat hara yang rendah memiliki pH antara 4 sampai 6. Tanah ini cocok untuk tanaman yang keras namun rentan terhadap erosi. Tanah aluvial terdapat ditempat air mengalir yang berasal dari sungai-sungai dan mata air. Hal ini karena tanah tersebut merupakan endapan yang terbawa dari hulu mata air ke hilir. Bahkan di kolam akan banyak ditemui tanah aluvial bertekstur lempung.

Lokasi Kelurahan Cibunigeulis terletak di sebelah timur Kota Tasikmalaya dengan luas wilayah $34 \mathrm{~km}^{2}$. Jarak dari pusat pemerintahan Kota tasikmalaya sejauh $7 \mathrm{~km}$, dari pusat Kecamatan Bungursari sejauh 1,5 km dan dari Singaparna sebagai pusat ibu kota Kabupaten Tasikmalaya adalah $10 \mathrm{~km}$. Adapun aksesibilits dengan lokasi kegiatan pariwisata lainnya adalah dekat dengan taman wisata Situ Gede (Kota Tasikmalaya) dan objek wisata Gunung Galunggung (Kabupaten Tasikmalaya)

Sumberdaya perairan di Kelurahan Cibunigeulis yang digunakan untuk memelihara ikan terdiri dari kolam, sawah dan sungai. Sumber air yang digunakan untuk pengairan berasal dari sumber mata air di Kelurahan Cibunigeulis yaitu dari Gunung Cariu Cayur, Gunung Cariu, Gunung Kokosan, Legok Nangka dan Ranca Sarenggang yang digunakan untuk mengairi sawah penduduk dan kolam ikan.

Penggunaan kolam menurut Ma'arif (2017:11) harus disesuaikan dengan karakteristik ikan dan kemampuannya beradaptasi dengan lingkungan. Secara kepemilikan kolam yang digunakan sebagai kolam milik pribadi dan kolam yang disentralkan. Kolam milik pribadi berarti diusahakan untuk kepentingan pribadi, sedangkan kolam yang disentralkan akan digunakan oleh anggota kelompok petani ikan dengan sistem bagi hasil.

Kolam yang disentralkan biasanya dimiliki oleh ketua kelompok pembudi daya ikan yang secara sukarela digunakan untuk kepentingan kelompok. Kolam yang disentralkan terdapat pada kelompok pembudi daya ikan. Terdapat beberapa jenis kolam ikan yang digunakan untuk budi daya diantaranya kolam tanah, kolam semen, kolam semi semen dan tanah, 
kolam keramba, sungai keramba, dan minapadi.

Pembudi daya memiliki jumlah kolam berbeda-beda. Untuk kolam beton, pembudi daya biasanya memiliki 1-11 kolam dengan luas perkolam $400 \mathrm{~m}^{2}-800$ $\mathrm{m}^{2}$. Pembudi daya yang memiliki kolam tanah biasanya hanya berjumlah 1-5 buah kolam dengan luas kolam kurang dari 200 $\mathrm{m}^{2}-800 \mathrm{~m}^{2}$. Pembudi daya yang memiliki kolam keramba biasanya hanya memiliki 1-2 kolam dengan luas $200 \mathrm{~m}^{2}-400 \mathrm{~m}^{2}$.

Kolam semen dimiliki oleh pembudi daya yang bermodal besar. Sedangkan untuk kolam semi semen dan tanah dimiliki oleh pembudid daya dengan modal yang tidak terlalu besar. Hal ini terjadi karena penembokan dilakukan setelah pembudi daya memiliki keuntungan dari perikanan. Sedangkan untuk kolam keramba biasanya digunakan oleh pembudi daya ikan lele. Pembudi daya ikan lele dilakukan dengan sistem polikultur ikan lele dan ikan nilem. Ikan lele disimpan di tengah kolam dan dibatasi dengan jaring agar ikan lele tidak bersatu dengan ikan nilem dan tidak memakan ikan nilem yang ada. Dan kolam keramba juga digunakan para pembudi daya ikan untuk memelihara benih ikan agar mempermudah pemeliharaannya.

Kolam minapadi merupakan kegiatan budi daya penyelang dalam pemeliharaan ikan sebelum menanam padi.
Kolam minapadi menurut Khairuman dan Amri (2008:3) adalah pemeliharaan ikan yang dilakukan bersamaan dengan penanaman atau pemeliharaan padi. Pembudi daya ikan yang memelihara ikannya di sawah baik sebagai minapadi ataupun penyelang meskipun dalam jumlah yang sedikit apat dilakukan secara terus menerus tergantung kemampuan daya dukung sawah. Konsep penyelangan dengan cara menunggu selama 25 hari agar benih padi siap untuk di tanam, maka sawah akan kosong.

Pembudi daya ikan memelihara beragam jenis ikan. Ikan yang dapat dipelihara menurut Cahyono (2000:1) terdiri dari sepat siam, toman, gabus, tawes, sengkaring, mujair, lele, mas, gurame, nila, jendil, tagih, betok, hampala, nilem, tambakan, jelawat, patin, biawan, lampan, baung, betutu. Ikan yang dipelihara diantaranya adalah ikan mas, nila, nilem, gurame, mujair, tambakan, tawes, lele, patin dan sepat. Ikan yang paling banyak dipelihara adalah ikan mas, nila, nilem, tawes dan mujair. Dalam kegiatan pemeliharaan jarang mengganti jenis ikan yang dipelihara, dikarenakan pembudi daya menjadi pemasok jenis ikan tertentu untuk para pengepul ikan, sehingga jenis ikannya tidak diganti. Contohnya para pengepul yang mencari ikan gurame akan mendatangi pembudi daya gurame yang sudah ia kenal 
sebelumnya. Faktor lainnya karena pengalaman yang didapatkan setelah memelihara ikan tertentu menjadi pengetahuan untuk proses budi daya selanjutnya. Sehingga ikan yang lebih banyak digalakan pada adalah nila karena dalam waktu singkat atau 3 bulan sudah dapat dipanen.

Proses produksi budi daya perikanan air tawar terdiri dari beberapa tahapan, yaitu persiapan kolam, pemupukan, pemeliharaan induk, pemijahan, penetasan telur, pendederan, pembesaran, pemanenan, pengolahan, pemasaran. Untuk semua proses produksi ini tidak di lakukan oleh satu pembudi daya. Pembudi daya biasanya berfokus pada beberapa proses saja. Tahap persiapan kolam, kolam yang akan digunakan terlebih dahulu dikeringkan, dibersihkan dari kotoran, rumput-rumput. Tanggul yang rusak harus ditambal, tanggul yang retak dan lubanglubang kecil harus disumbat dengan tanah liat berpasir (Djarijah, 1996: 45).

Tahap pertama mempersiapkan kolam dengan melakukan pengeringan kolam sehabis panen, kemudian digunakan kapur untuk mensterilkan dan menyeimbangkan $\mathrm{pH}$ agar tidak asam disertai dengan penebaran pupuk organik menumbuhkan fitoplankton. Selanjutnya dilakukan proses pemijahan, dengan cara induk yang dipilih adalah induk dengan pertumbuhan yang baik dan sehat.
Pembudi daya melakukan pemijahan lebih dari 10 kali dalam setahun tergantung jenis ikan, luas kolam, banyaknya induk yang dimiliki. Pendederan adalah pemeliharaan ikan kecil dengan ukuran 1-3 cm menjadi ikan berukuran 5-8 $\mathrm{cm}$ atau lebih. Dari pendederan dilanjutkan dengan kegiatan pembesaran untuk menghasilkan ikan ukuran konsumsi. Biasanya ikan yang dipasarkan adalah ikan yang sudah berukuran 300-500 gram per ekor. Untuk ikan nila biasanya yang diminta adalah 1 kilo 8 ekor dengan waktu 3 bulan, sedangkan untuk permintaan restauran biasanya 1 kilo 4 ekor atau 1 kilo 2 ekor, dan ini akan memakan waktu 5 bulan. Pembesaran ikan akan menghabiskan modal yang sangat banyak karena pemberian pakan pelet akan semakin banyak ketika ikan semakin membesar.

Pemanenan juga dapat sistem panen total atau panen selektif. Panen total adalah panen yang mengambil ikan yang siap panen secara keseluruhan tanpa kecuali. Sedangkan panen selektif dilakukan jika ukuran ikan yang dipelihara tumbuh tidak seragam sehingga yang dipanen hanya ikan dengan ukuran tertentu (Khairuman dan Amri, 2008:76). Masa pemanenen dilakukan dengan cara yang berbeda sesuai ukuran ikannya. Untuk ikan ukuran konsumsi, kolam ikan akan dikeringkan perlahan-lahan. Untuk ikan berukuran 3 $\mathrm{cm}$ maka akan digunakan jaring. Untuk 
ikan berukuran larva, ikan akan dipanen menggunakan kain karna ukurannya yang sangat kecil sehingga harus berhati-hati dan harus menggunakan bahan yang lembut. Pembudi daya ikan rata-rata dalam waktu 3 bulan mampu memanen ikan konsumsi sebanyak $3000 \mathrm{~kg}$. Hal ini dipengaruhi luas kolam tempat produksi rata-rata mencapai $800 \mathrm{~m}^{2}$ dan pemberian pakan pelet dalam 2 kali sehari.

Kegiatan pemasaran ikan tergantung dari tingkat permintaan dan penawaran yang ada. Pemasaran menurut Hanafiah dan Saefuddin (2006:109) adalah segala usaha atau tindakan yang berhubungan dengan bergeraknya barang dan jasa sejak dari produsen sampai konsumen. Setelah kegiatan pemanenen, ikan yang telah diproduksi akan dijual ke pengepul ikan serta depo ikan yang ada di Kota Tasikmalaya. Sebagian pembudi daya ada yang langsung menjual ikannya ke Pasar Cikurubuk. Pemesanan ikan dapat berasal dari Kota Tasikmalaya maupun luar Kota Tasikmalaya. Luar Kota Tasikmalaya terdiri dari Jakarta, Bandung, Sukabumi, Kabupaten Tasikmalaya dan Canjur. Pengepul ikan akan menggunakan mobil pick up jika ikan yang dibeli diatas 3 kuintal. Namun sebagian besar ikan akan diangkut menggunakan motor, karena sekali panen rata-rata pembudi daya ikan hanya mampu menghasilkan 3 kuintal ikan.
Kegiatan minawisata hakekatnya merupakan suatu bentuk kegiatan pariwisata yang berbasiskan pada kegiatan perikanan baik darat dabn perairan. Hal ini dapat dilakukan langsung oleh masayarakat atau pun di kelola secara individu. Namun yang menjadi tolak ukur keberhasilan minawisata adalah adanya peran serta masyarakat untuk bisa membangun kegiatan perikanan berdasarkan kegaiatan pariwisata. Terdapat beberapa potensi kegiatan minawisata yang dapat dilakukan pada kegiatan budidaya perikanan air tawar diantaranya kegiatan memancing, kuliner dan pameran ikan.

Memancing merupakan kegiatan menangkap ikan terkait dengan kegiatan pekerjaan dan olah raga terbuka (outdoor). Kegiatan pemancingan menurut Wudianto dkk (1999) dapat dilakukan diperairan umum dan kolam khusus. Perairan umum merupakan permukaan bumi yang secara permanen digenangi air dengan kepemilikannya bersifat umum dan bukan milik perseorangan, contohnya: waduk, sungai, danau, situ, rawa, dan bendungan. Sedangkan kolam khusus yaitu secara teknis merupakan suatu perairan buatan yang luasnya terbatas dan dibuat manusia (diisi air, dikeringkan, diatur menurut kehendak kita). Untuk penggunaan kolam ikan dibutuhkan pemelihaaran yang khusus seperti menjaga kestabilan debit air 
agar tidak kekurangan, menjaga $\mathrm{pH}$ air agar tidak terlalu asam, dibuatkan bedengbedeng pemancingan yang nyaman untuk kegiatan memancing dan dimasukkan ikan yang bervariasi biar pengunjung bisa memilih jenis ikan yang akan dipancing. Adapun potensi penggunaan kolam untuk kegiatan memancing yang dapat dilakukan adalah dengan sewa lapak, kolam harian, borong kolam, sistem kiloan, pancing lomba dan pancing galatama.

Kegiatan kuliner merupakan suatu usaha untuk mengolah bahan baku menjadi barang jadi dengan nilai cipta dan rasa. Ragam olahan kegiatan kuliner sangat bergantung dari jenis ikan yang akan digunakan. Dari segi jenis dan ukuran akan menciptakan variasi kuliner dalam kegiatan minawisata. Semakin banyak maka akan menjadi daya tarik dan memiliki nilai komersil yang bagus. Produk olahan ini harus terkait dengan cita rasa lokal, sehingga masayarakat bisa mengembangkan keanekaragaman kuliner bersifat lokal dan bercita rasa nasional. Beberapa produk olahan ikan yang beragam mulai dari ikan bakar, ikan goreng, ikan pepes, ikan balado, pindang ikan, acar ikan, asam manis ikan, sate ikan, baso ikan, keripik ikan, kerupuk ikan, abon ikan dan gepuk ikan.

Kegiatan pameran ikan dalam minawisata bertujuan untuk mempromosikan produk unggulan perikanan yang ada di Kelurahan Cibunigeulis. Beberapa jenis ikan yang dipamerkan dapat berupa ikan konsumsi dan ikan hias. Ikan konsumsi yang akan dipamerkan seperti ikan mas, ikan gurame, ikan nila, ikan patin dan ikan lele. Sedangkan ikan hias air tawar yang dapat dipamerkan seperti ikan cupang, ikan guppy, ikan louhan dan ikan discus. Kegiatan pameran ini bisa dilakukan setiap 1 tahun sekali mengingat kegiatan pameran seperti ini tidak selalu ada disetiap wilayah.

\section{KESIMPULAN DAN SARAN \\ 1. Kesimpulan}

Potensi kawasan ekonomi untuk kegiatan pemeliharaan ikan dari segi lokasi yaitu Kelurahan Cibunigeulis yang sesuai dengan kondisi fisik dan daya dukung tempat pemeliharan yang ideal seperti kolam seperti kolam, tenaga kerja, pembibitan, pengetahuan dan modal. Dalam hal ini perlu proses tahapan dalam mengelola pemeliharaan ikan yang baik dan benar sehingga menghasilkan produk yang baik, diantaranya adalah tahap persiapan kolam, tahap pemupukan, tahap pemijahan, tahap penetasan telur menjadi larva ikan. Setelah itu memasuki tahap pendederan, tahap pembesaran, tahap pemanenan, tahap pengolahan dan tahap pemasaran. Adapun ikan yang di pelihara merupakan komoditas utama untuk 
kebutuhan konsumsi baik dalam kota dan luar kota.

Beberapa produk ikan diantaranya ikan mas, ikan lele, ikan mujair, ikan nila, ikan nilem dan ikan lainnya. Untuk kegiatan dalam skala usaha skala usaha besar, sedang dan kecil. Dari segi luas kolam, sebagian besar pembudi daya memiliki skala usaha besar dengan luas kolam lebih dari $400 \mathrm{~m}^{2}$. Dari segi penggunaan tenaga kerja sebagian besar pembudi daya ikan termasuk dalam skala usaha kecil. Dan untuk modal menggunakan modal sendiri dan meminjam. Sebagian kecil pembudi daya setelah usahanya berhasil akan meminjam moda ke bank untuk mengembangkan usahanya. Dan dari segi kegiatan minawisata diantaranya mempunyai peluang untuk kegiatan memancing, kuliner dan pameran perikanan.

\section{Saran}

Adapun saran dalam penelitian ini sebagai berikut:

a. Perlu adanya keikutsertaan masyarakat dan pemerintah sebagai pendorong agar dapat menjadi kegiatan wisata berbasis potensi.

b. Mambangun minawisata sebagai proses pembangunan berdaya saing antar wilayah sehingga dapat menjadikan kemandirian bagi wilayah yang ada di pinggiran kota.

\section{E. DAFTAR PUSTAKA}

Ayodya. (2010). Cara Jitu Hitung Modal Usaha. Jakarta: PT Elex Media Komputindo.

Banowati dan Sriyanto. (2013). Geografi Pertanian. Yogyakarta: Ombak.

Cahyono, Bambang. (2010). Budi Daya Ikan Air Tawar Ikan Gurami, Ikan Nila, Ikan Mas. Yogyakarta: Kanisius.

Hanafiah dan Saefuddin. (2006). Tataniaga Hasil Perikanan. Jakarta: UI Press.

Khairuman dan Amri. (2008). Buku Pintar Budi Daya 15 Ikan Konsumsi. Tangerang: Rajawali.

Khairuman dan Amri. (2008). Buku Pintar Budi Daya 15 Ikan Konsumsi. Tangerang: Rajawali

Ma'arif. (2017). Cara Sukses Budi Daya Ikan Gurami. Yogyakarta: Bio Genesis

Nurdin, dkk. (2017). Hukum Perikanan. Malang: UB Press

Priyono. (2016). Metode Penelitian Kuantitatif. Zifatama Publishing: Sidoarjo.

Subarnas, dkk. (2007). Terampil Berkreasi. Bandung: PT. Grafindo Media Pratama.

Wudianto, Maniswara, Anung WAP. (1999) Memancing di Perairan Tawar dan Laut. Cetakan Keempat. Jakarta : Penebar Swadaya. 